\title{
Case study - integrated planning to enhance closure outcomes for the Pardoo Mine in Western Australia
}

\author{
S. Mackenzie Mine Earth Pty Ltd, Australia \\ T. Beattie Atlas Iron Ltd, Australia \\ N. Burne Mine Earth Pty Ltd, Australia \\ R. Haymont Trajectory Pty Ltd, Australia
}

\begin{abstract}
The Pardoo Direct Shipping Ore Project is owned by Atlas Iron Limited and is located in the Pilbara region of Western Australia. Iron ore mining commenced in October 2008, and under the current mine plan ore reserves will be depleted during 2014. The project is significant to Atlas as its first producing mine, and the company has committed to achieving a high standard for closure planning and implementation.
\end{abstract}

Closure planning commenced during the feasibility stage of the project in 2008. Detailed closure planning was initiated during 2010 and included the use of gap analysis and risk assessment to identify closure opportunities and set planning priorities. A program of targeted investigations was then undertaken to resolve gaps and risks and to enable the development of a detailed mine closure plan.

Atlas will demonstrate closure performance using robust measures, including closure objectives and criteria, to facilitate lease relinquishment in a planned and timely manner. Closure objectives and criteria have been developed in consultation with stakeholders.

Atlas has integrated closure planning outcomes into the operational phase of the project to realise financial and operational efficiencies. The approach that Atlas has adopted will contribute to enhanced closure outcomes for the project.

\section{Introduction}

The Pardoo DSO Project is an iron ore mine owned and managed by Atlas Iron Limited. It is located approximately $75 \mathrm{~km}$ east of Port Hedland in the Pilbara region of Western Australia (Figure 1). The project consists of six deposits that have been mined via 11 open pits at a rate of approximately 3 million tonnes per annum (Mtpa). Ore is crushed and screened at the project prior to off-site transport and shipping from Port Hedland. Mining commenced in December 2008, and under the current mine plan ore reserves will expire by March 2014.

Closure planning commenced during the feasibility stage of the project with the development of a conceptual mine closure plan in 2008. Detailed closure planning was initiated during 2010 in response to project commitments and Atlas's aspiration to understand and manage closure risks and opportunities. The closure planning process that Atlas adopted aligns with the concept of progressive mine closure planning (Mackenzie et al., 2006, 2008) and meets the requirements of the Western Australian mine closure guidelines as a minimum (DMP and EPA, 2011).

The project is significant to Atlas as its first producing mine, and the company has committed to achieving a high standard for closure planning and implementation. High standards have been achieved through innovative and integrated planning, open engagement of internal and external stakeholders and external peer review. 


\section{Project summary}

Mining of iron ore is undertaken via conventional drill and blast, load and haul open pit mining methods from 11 pits (Bobby, Glenda, Alice East, Alice West, Alice Extension, Connie, South Limb, South Limb West, Chloe, Emma and Olivia) (Figure 2). Ore is crushed, screened and stockpiled on-site and then trucked using road trains to Port Hedland via the Great Northern Highway. Ore is shipped from the Utah Point bulk commodities berth at Port Hedland. Waste rock from the Project is stored in six waste rock landforms (Bobby/Glenda, Alice, South Limb, South Limb West, Chloe and Olivia/Emma).

Closure works commenced during 2013 and will be finalised in 2014. Post closure monitoring will be undertaken to measure performance against agreed closure objectives and criteria. Atlas aims to meet all closure objectives and criteria and achieve lease relinquishment 10 years after completion of closure works.

\section{Regional setting and climate}

The project is located in the Town of Port Hedland local government area. The dominant land use in the region includes pastoral and mining activities, Aboriginal Reserves, conservation areas and urban development. The population of Port Hedland is estimated to be approximately 20,000 people and the main economic drivers in the region are commercial fishing and the minerals and energy industry (Town of Port Hedland, 2013). The Port Hedland port is the largest export tonnage port in Australia.

The project tenements overlap the De Grey pastoral station leases and the De Grey River Water Reserve, which supplies scheme water to Port Hedland and is classified as a Priority 1 water reserve. The project is also located approximately $10 \mathrm{~km}$ west of the De Grey River and $10 \mathrm{~km}$ east of the Leslie Saltfields, both of which are registered wetlands of national significance.

The climate of the region is arid tropical (Kendrick and Stanley, 2001), with hot summers and warm winters. Annual recorded rainfall fluctuates from year to year. A mean annual rainfall of $320 \mathrm{~mm}$ has been recorded at the Pardoo Station, $50 \mathrm{~km}$ east of the project. Most rainfall occurs during the summer as a result of highintensity events related to cyclonic activity.

\section{$4 \quad$ Closure investigations}

Gap analysis and risk assessment were used to identify closure opportunities and to set planning priorities. Targeted closure investigations were then undertaken to address gaps and risks, the outcomes of which enabled the development of a detailed mine closure plan. Closure investigations consisted of groundwater modelling, surface water drainage studies, soils assessments, landform design (including erosion modelling and geological mapping) and rehabilitation planning. 


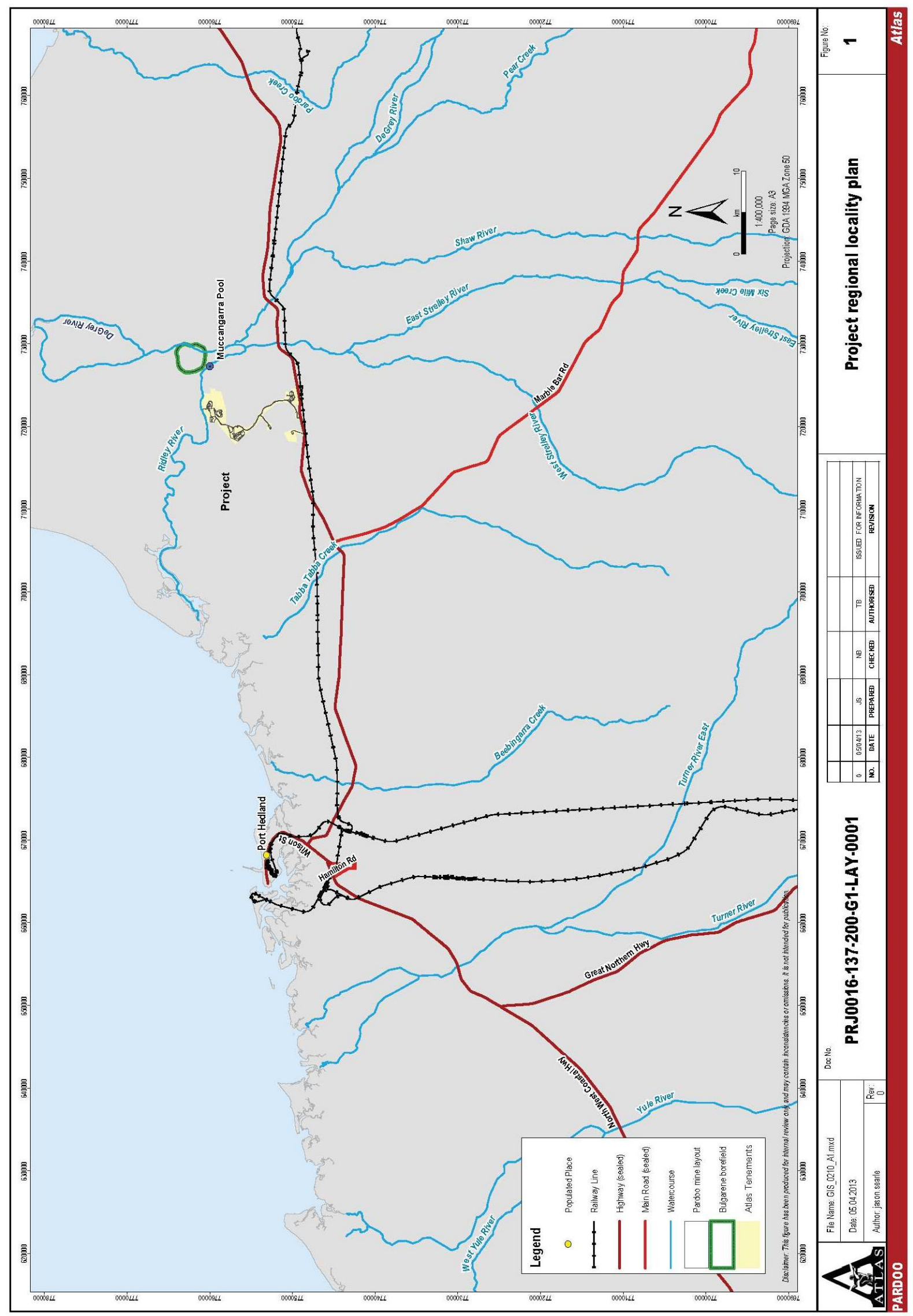

Figure 1 Regional locality plan 


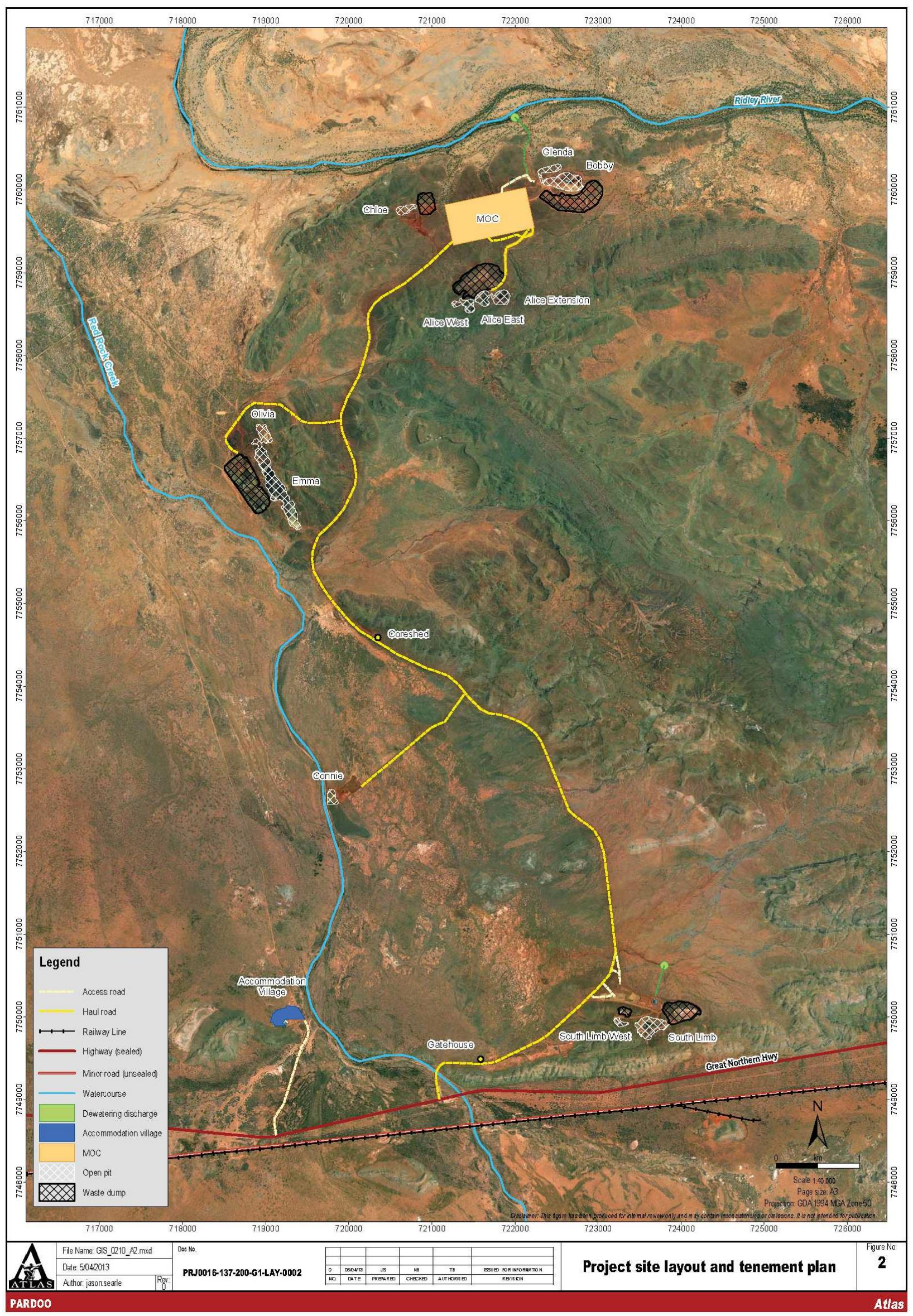

\section{Figure 2 Project layout}




\subsection{Risk assessment}

A series of mine closure risk assessment workshops were undertaken for the project. The objectives were to identify, rank and prioritise risks, to develop management options for risk events that could compromise closure objectives and to assist with managing uncertainty. The risk assessment process aligned with the Australian and New Zealand Risk Management Standard (AS/NZ 31000:2009).

Three phases of mine closure were considered when undertaking the risk assessment: pre-closure planning, closure implementation and post closure. Individual workshops were held to assess the risks associated with each phase and were attended by relevant stakeholders. As an example, four key risks from the phase three risk assessment are presented in Table 1.

Risk assessment outcomes were used to guide the development of closure plans for each relevant domain. Atlas will progressively review the phase three mine closure risk assessment throughout the post-closure period, engaging relevant stakeholders where required.

\section{Table 1 Four key risks from the phase three risk assessment}

\begin{tabular}{|c|c|c|}
\hline Event & Cause & Control Strategies \\
\hline $\begin{array}{l}\text { Poor } \\
\text { revegetation } \\
\text { outcomes }\end{array}$ & $\begin{array}{l}\text { Insufficient or hostile soil; } \\
\text { inappropriate or poor quality seed; } \\
\text { erosion; excessive fire; grazing } \\
\text { pressure; weeds; poor climatic } \\
\text { conditions }\end{array}$ & $\begin{array}{c}\text { A comprehensive rehabilitation plan has been } \\
\text { developed; detailed design of landforms and } \\
\text { surface water controls has been undertaken; } \\
\text { post-closure monitoring and maintenance will be } \\
\text { undertaken; temporary fencing around } \\
\text { rehabilitation areas }\end{array}$ \\
\hline $\begin{array}{l}\text { Unauthorised } \\
\text { access to open } \\
\text { pits }\end{array}$ & $\begin{array}{c}\text { Abandonment bund failure; bund } \\
\text { not constructed according to } \\
\text { guidelines }\end{array}$ & $\begin{array}{c}\text { Bunds designed to meet guideline requirements; } \\
\text { detailed design of landforms and surface water } \\
\text { controls has been undertaken; closed unused } \\
\text { roads and tracks }\end{array}$ \\
\hline $\begin{array}{l}\text { Failure of } \\
\text { engineered } \\
\text { structures }\end{array}$ & $\begin{array}{l}\text { Landforms not constructed } \\
\text { according to designs; design } \\
\text { criteria not suitable; erosion; } \\
\text { specifications not achievable; } \\
\text { inadequate monitoring or } \\
\text { maintenance }\end{array}$ & $\begin{array}{c}\text { Detailed design of landforms and surface water } \\
\text { controls has been undertaken; QA/QC will be } \\
\text { undertaken to implement designs accordingly; } \\
\text { post-closure monitoring and maintenance will be } \\
\text { undertaken }\end{array}$ \\
\hline $\begin{array}{l}\text { Stakeholder } \\
\text { expectations } \\
\text { are not met }\end{array}$ & $\begin{array}{l}\text { Stakeholder engagement does not } \\
\text { continue after mine closure }\end{array}$ & $\begin{array}{l}\text { Ongoing stakeholder engagement will be } \\
\text { undertaken; feedback on closure performance } \\
\text { will be communicated to stakeholders }\end{array}$ \\
\hline
\end{tabular}

\subsection{Groundwater}

A regional hydrogeological investigation was undertaken in 2012. The investigation assessed the potential for impacts on local receptors, including a culturally sensitive pool (Muccangarra Pool) and water reserve (Bulgarene borefield). Increases in pit lake salinity and metal concentrations were predicted due to the formation of an evaporative sink. Flowpath analysis found it unlikely that the receptors will be influenced by pit lake seepage, however, because seepage rates were generally low.

\subsection{Surface water}

Regional modelling of surface water flows during both 1:100 year average recurrence interval and peak maximum flow rainfall events were undertaken for the project area. Modelling highlighted the potential impacts of these rainfall events on the constructed project landforms. A number of management measures were recommended for each domain based on flooding predictions, including flood and flow protection 
(bunds and diversion structures) on and around waste rock landforms, open pits and other disturbance areas.

\subsection{Soils assessment}

An assessment of the quality and inventory of stockpiled topsoil and potential subsoil resources was undertaken during 2012. The physical and chemical characteristics of topsoil stockpiles and subsoil resources were also assessed. Most stockpiled topsoils were considered suitable for use on flat areas and in some cases on lower/shallow slopes because of their erosive nature. The physical characteristics of subsoil resources were generally more favourable than stockpiled topsoil for use on waste landform slopes, because they were generally less erosive.

A soil inventory revealed that there will be a deficit in terms of the volume of soil required for rehabilitation compared with the volume available in stockpile. Harvesting of topsoil during abandonment bund clearing and selective harvesting of subsoil will be sufficient to mitigate this deficit during closure works.

\subsection{Landform design}

An investigation to develop an appropriate closure design for each waste rock landform was undertaken. The investigation included slope erosion modelling, SIBERIA landform evolution modelling and a geological assessment of slope stability. The geological assessment found that the waste rock landforms generally consisted of blocky and competent high-stability waste rock. There were some minor zones of medium and low-stability rock that may require rock armouring.

Both a single and a double batter landform design was proposed for project landforms that incorporated the following key design principles (Figures 3 and 4):

- Minimise the potential for water flow onto landform batters.

- Encourage surface water infiltration on landform surfaces.

- Reprofile the landform batters to a concave shape, comparable to an eroded slope after 250 years of modelled erosion.

- Constrain slope lengths to less than $100 \mathrm{~m}$.

- Limit vertical batter heights to $20 \mathrm{~m}$, beyond which a mid-slope berm is recommended.

- Berms should accommodate peak maximum flows and should be level.

- Final batter surfaces should consist of suitably coarse and durable rock. Armouring rock will be placed where required.

- Landform surfaces will be sheeted with topsoil where available or subsoil.

- Landform surfaces will be cross-ripped on the contour.

- Spread area specific seed mix (native grass, shrub and tree species).

- Sediment control measures will be implemented around the perimeter of each waste rock landform.

- Fencing will be installed where practicable to minimise grazing during vegetation establishment. 


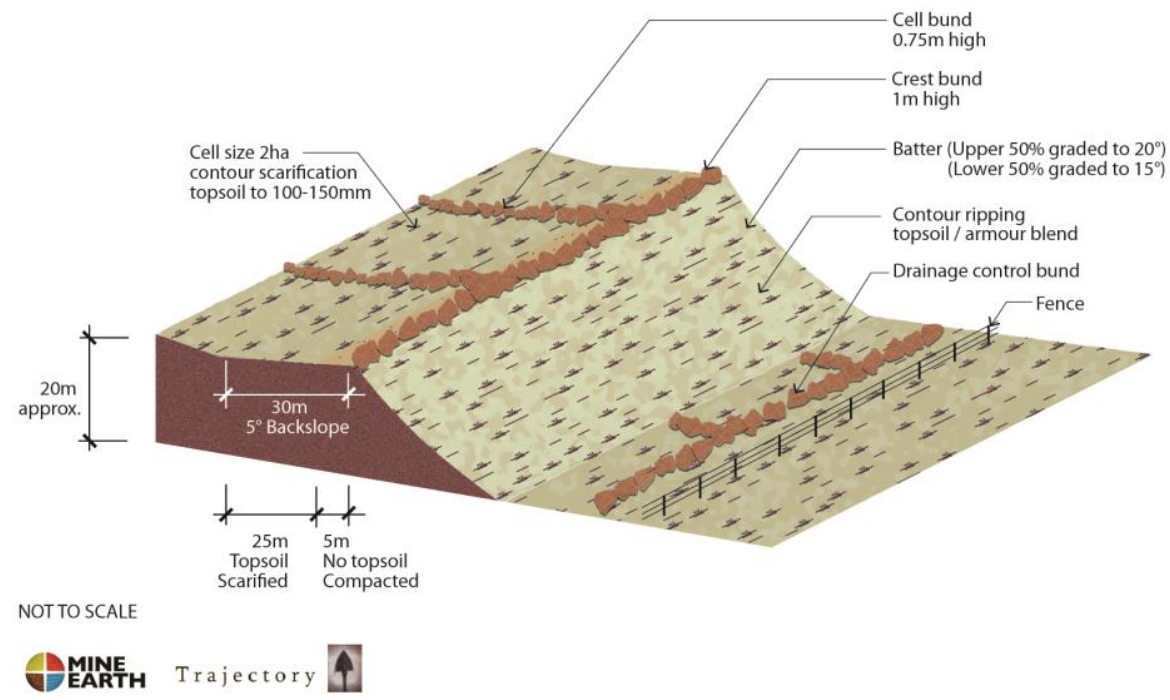

\section{Figure 3 Single batter landform design}

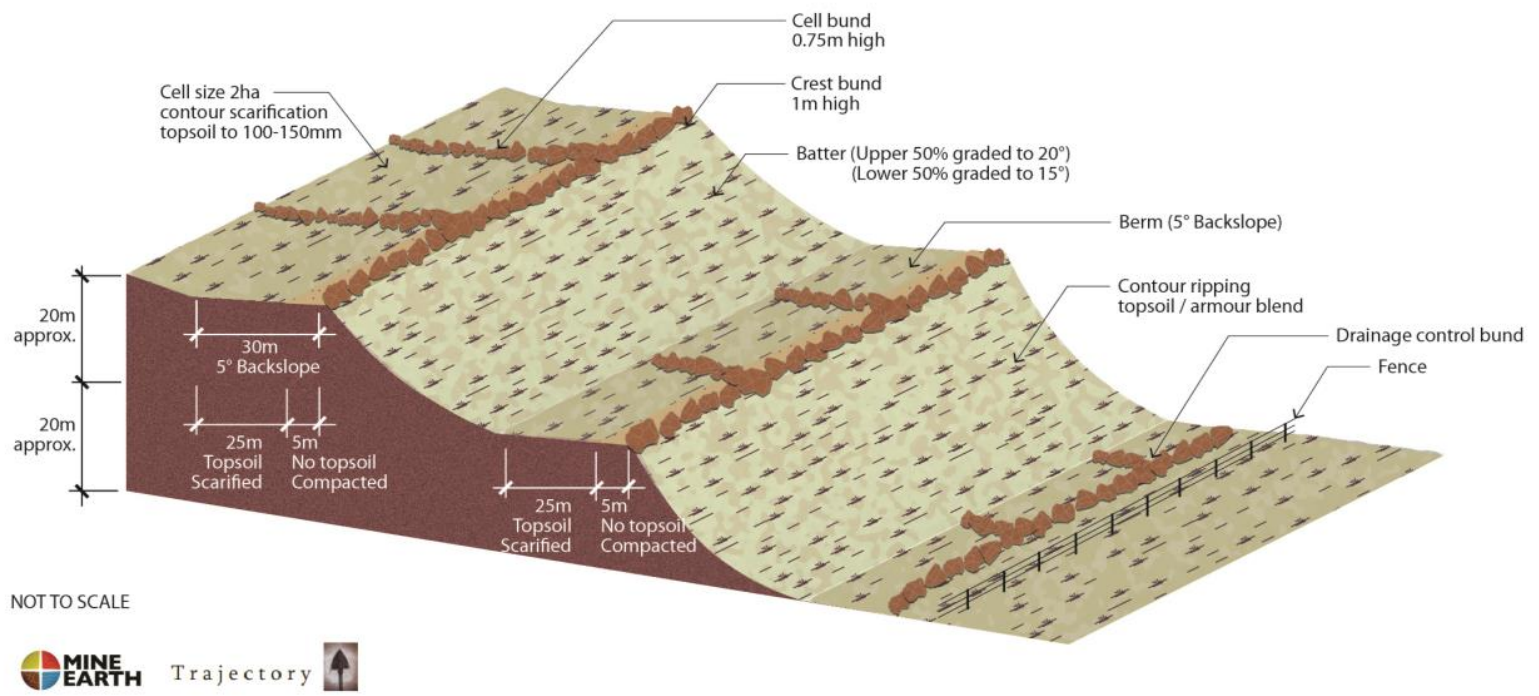

\section{Figure 4 Double batter landform design}

\subsection{Rehabilitation planning}

A detailed rehabilitation plan was developed to provide recommendations in relation to native seed procurement and management, topsoil reconciliation, surface treatments and revegetation.

Domain-specific native seed mixes have been developed based on species represented in surrounding floristic communities, and provenance seed will be sourced where possible. Seed will be treated to break dormancy, and viability testing will be undertaken for major seed batches. Atlas is also considering a seed inoculant to assist with plant establishment, as an alternative to fertiliser.

Contour ripping using survey or GPS support will be undertaken, and seed will then be applied at a rate of $10 \mathrm{~kg} / \mathrm{ha}$ for waste rock landforms and $6 \mathrm{~kg} / \mathrm{ha}$ for all other disturbance areas. 


\section{$5 \quad$ Stakeholder consultation}

Stakeholders often have a long-term interest in an area beyond the operating phase of a mine. Atlas recognises the importance of consulting with stakeholders in relation to mine closure, to provide an avenue for effective participation in the closure process.

A closure consultation plan was developed and implemented; it consisted of a series of detailed meetings with relevant primary and internal stakeholders. Project stakeholders included Commonwealth and state government agencies, native title and traditional owner groups, pastoral lease holders and other local/regional groups. Stakeholders were able to directly participate in the closure planning and decision making process.

Stakeholder meetings were scheduled in both Port Hedland and Perth to encourage attendance. Initial meetings provided background information and details of closure knowledge gaps to encourage stakeholders to contribute to the design of the closure investigations. Subsequent meetings were used to present the outcomes of the closure investigations and encourage stakeholders to contribute to the outcomes. Later meetings were used to encourage participation in developing closure objectives, closure criteria and the post-closure monitoring strategy.

In addition to the scheduled meetings, follow-up meetings were held with individual stakeholders to discuss specific mine closure issues and requests. Atlas will consult with primary stakeholders on an ongoing basis.

\section{Closure performance}

Atlas will demonstrate closure performance using robust measures, including closure objectives and criteria, with the aim to achieve lease relinquishment in a planned and timely manner.

Atlas has developed a mine closure 'vision' to describe the intended future state of the project area after mine closure. The mine closure plan states:

"Rehabilitated areas will be safe and stable and the Project will have no significant impacts to Bulgarene borefield or Muccangarra Pool. Revegetation will be self-sustaining and will support limited pastoral land use over time. General access to the site will be limited and any residual infrastructure will be managed by a new owner" (Atlas, 2013).

The vision is supported by closure objectives that, in line with the ANZMEC framework (ANZMEC and MCA, 2000), are site-specific and cover a range of aspects. Closure objectives, criteria and standards have been developed for five aspects: safety, assets, groundwater, vegetation and surface water. The closure objectives for the project are:

- Closed areas will be designed to deter access.

- Infrastructure will be removed or left in situ where agreed.

- The rehabilitation will support self-sustaining vegetation, which can be reasonably achieved.

- The project will have no significant adverse impacts on Bulgarene borefield and Muccangarra Pool.

- Uncontrolled surface water flows and impacts to surface water will be minimised.

Not all objectives apply to all project domains. The closure objectives, criteria and standards have been developed in consultation with relevant industry specialists and representatives from relevant state government agencies. 


\section{$7 \quad$ Integrated planning}

Atlas has integrated the outcomes from the planning phase into the operational phase of the project and has developed a practical strategy for closure implementation. This will enable the company to realise substantial financial and operational efficiencies.

Scopes and tender documents have been developed based on the outcomes of the planning process and have facilitated selection of appropriate closure contractors in line with closure objectives. Closure work instructions have also been prepared through the planning process, whereby technical details have been summarised in the work instructions to provide detailed information to supervisors, contractors and operators, so that conformance with closure designs and standards can be achieved. Closure supervisors, contractors and operators also undergo specific inductions to ensure that the appropriate specifications and standards are interpreted into the closure implementation phase.

Operational personnel have been actively engaged to identify efficiencies and opportunities, including the selection, segregation and strategic stockpiling of competent run-of-mine waste rock for various uses during closure works. Through early planning and initiation of closure works during the operating phase of the project, Atlas will realise efficiencies in relation to management and technical support for closure implementation.

Ongoing project management involves an iterative process between the project managers, technical specialists, supervisory personnel and contactors to identify project changes requiring technical or operational responses.

\section{Conclusions}

The comprehensive and integrated strategy that Atlas has adopted will contribute to enhanced closure outcomes for the project. Leading baseline studies, closure investigations and modelling have been undertaken to develop detailed plans that respond to the local climatic, physical and biological attributes of the project. Operational activities have been optimised to minimise closure costs and also enhance outcomes. This has been achieved through the collaboration of a multidisciplinary team that has effectively balanced technical and physical aspects with the requirements and aspirations of internal and external stakeholders.

The detailed planning process has been informative for Atlas and has resulted in positive planning outcomes for their other projects.

\section{References}

ANZMEC (Australian and New Zealand Minerals and Energy Council) and MCA (Minerals Council of Australia) (2000) Strategic Framework for Mine Closure, Canberra, Australia.

Atlas Iron Limited (2013) Pardoo Mine Closure Plan, May 2013, http://www.atlasiron.com.au/IRM/Company/ShowPage.aspx?CPID=1320, viewed April 2013.

DMP and EPA (2011) Department of Mines and Petroleum and Environmental Protection Authority in Western Australia. Guidelines for Preparing Mine Closure Plans, June 2011, http://www.dmp.wa.gov.au/documents/Mine_Closure(2).pdf, viewed April 2013.

Kendrick, P. and Stanley, F. (2001) Pilbara 4 (PIL4 - Roebourne synopsis), A biodiveristy audit of Western Australia's 53 biogeographical subregions in 2002, viewed 19 January 2011, http://www.dec.wa.gov.au/pdf/science/bio_audit/pilbara04_p581-594.pdf.

Mackenzie, S.I., Lacy, H.W.B. and Koontz, D. (2006) Benefits of planned versus unplanned mine closure and strategies for both, in Proceedings First International Seminar on Mine Closure (Mine Closure 2006), A.B. Fourie and M. Tibbett (eds), 13-15 September 2006, Perth, Australia, Australian Centre for Geomechanics, Perth.

Mackenzie, S.I., Mitchell, I. and McGuire, C. (2008), Progressive rehabilitation and closure planning using GIS-based software at the Mungari project, Western Australia, in Proceedings of the Goldfields Environmental Management Group Conference, Kalgoorlie, Western Australia.

Town of Port Hedland (2013) http://www.porthedland.wa.gov.au, viewed April 2013. 
